\title{
4. Thirty-eight years toiling in the vineyard of public service ${ }^{1}$
}

\author{
Ric Smith
}

\begin{abstract}
After a brief career in the West Australian secondary school system, Ric Smith joined the Department of External Affairs in 1969. In that department - and its successor, the Department of Foreign Affairs and Trade - he held numerous important positions, including postings in New Delhi, Tel Aviv, Manila and Honolulu. In 1992 Smith was appointed Deputy Secretary in DFAT with responsibility for Australia's relations with Asia. He acted as Secretary of DFAT for much of the period from December 1992 to May 1993. From March 1994 to the end of 1995, Ric Smith served on secondment to the Department of Defence as Deputy Secretary, Strategy and Intelligence, before being appointed as Australian Ambassador to China in February 1996. He served there, and as non-resident Ambassador to Mongolia, until February 2000. From January 2001 to October 2002, he served as Australia's Ambassador to Indonesia. During this time, Bali was bombed and he, along with many others, played a major role in the recovery and repatriation of Australians. Ric Smith returned to Canberra in November 2002 to commence his role as Secretary of the Department of Defence, from which he retired in November 2006.
\end{abstract}

I am honoured to be the first retiring Australian public servant to have been invited to give a valedictory address. Many more distinguished colleagues have retired without such an opportunity. Let me start with a disclaimer. In preparing for this occasion I have been conscious that in other realms, and perhaps especially the United Kingdom, there is something of a tradition on occasions such as this of great oratory built around grand visions of the civil service as an institution; visions in the UK case conceptualised around the triumph that was Trevelyan and the wonder that is Westminster. If you were looking forward to anything so grand - to a laying out of great wisdom and intellectual riches about the Australian Public Service; where it has been and whither it is bound, then you will be disappointed. Instead I wish to present the reflections of one who has toiled in the vineyard of the Australian Public Service these past 38 years more as a tradesman than a philosopher - much less an artist or a visionary. It will be in large part a narrative tale, with a few thoughts born of long experience of the Westminster-with-Canberra-characteristics system we now have. My time in the APS has been fun, practical, sometimes quite hard even painful - but always worthwhile and fulfilling.

1 This was the first of the formal valedictory speeches delivered at a function organised by the Australian Public Service Commission in November 2006. 
With the benefit of hindsight

\section{The beginnings}

I was not destined to work in the Australian Public Service. Within my own extended family, over three generations that preceded me, there was only one public servant - an uncle who, so far as I could tell, had joined the service to support a gambling habit. Yet my first paid employment, at the end of my fifth year in high school, was as a postman, delivering the greeting cards which people sent to each other to mark Christmas 1961. I had an Australia Post-issued red bike and a cap, and when I got the chance to deliver the mail in my own suburb on one 40-degree-day I fully expected my mother to turn the neighbours out to watch me pedal down our own street on her majesty's service. For once - probably the only time - she let me down.

I did not return to the post office the next year, but while at university a few years later I found myself working over the Christmas holidays as a yardman at the Department of Supply at Karrakatta. If this first intrusion into the defence empire was not a sufficient augury, more portentous was my special assignment - to repaint some steel 'bailey bridges' which had been destined as an aid project in Indonesia but withheld because of the Indonesia-Malaysia confrontation of 1962-1966. I was told 'the bosses' believed they might soon begin to rust. So in a sandy paddock in Perth's blistering Christmas heat, I painted them from 7am until 10am each morning, then hung around the workshop for the rest of the day contributing little but learning much - if not about the public service, then about life. Years later as I crossed one 'bailey bridge' after another while being driven through Sumatra as Ambassador to Indonesia, I wondered whether these were the ones I had painted. Strangely, decades in the monsoonal climate had not rusted them. I must have painted them well.

It was through teaching that I made my first formal entry into public service. For the four years of my teacher training I was paid seven pounds two and ten pence a fortnight, without which going to university would have been more difficult. Teaching scholarships or bursaries were wonderful vehicles of social mobility in the 1960s. I taught for three years in rural and regional Australia, an experience which did more for me and my understanding of people than another ten years at university would have achieved. But rich as the teaching experience had been, there was plenty else on offer for the 15 per cent of us school leavers who completed university in the 1960s. In 1968, I applied for what we now call the 'graduate intake' in the Department of External Affairs and, to my mother's pride and my father's astonishment, was accepted. 


\section{Canberra in 1969}

Twenty-four of us joined External Affairs in 1969 at the end of what we remain confident was the only decade last century worth a damn. Most had tertiary qualifications that put mine in the shade: some had won prestigious scholarships; many spoke foreign languages and some, most amazing of all - to me at least - had travelled and even studied overseas. My starting salary was $\$ 3,820$. Honours graduates got more. The only woman in our group was paid a little less. I should not speak for the others, but I think I am right in saying that most of us were motivated to join External Affairs not by any interest in the public service as such, nor even any noble interest in serving the public, but rather by our own personal interest in international politics and foreign affairs.

Indeed, I do not think I had even heard the term 'public administration', and it was probably not until the 1980s that I first heard the term 'public policy'. And yet, this did not matter because in 1969 I did not appreciate that I had become involved in either. In the first year we did the usual three rotations in the department - which then occupied just the easternmost wing of what was called the 'Admin Building', now named after the Prime Minister of our day, John Gorton. My first rotation was in the aid branch (the whole of the Colombo Plan was run from one branch); my second in the conditions of service section. With most of my 'intake' colleagues assigned to high policy sections, it seemed to me that I had been picked from the start as a tradesman rather than a serious policy type. But I did learn a few tricks from some wily colleagues which stood me in good stead later, and I also got paid overtime which was acceptable to claim in the administrative areas of the department but not in the policy areas.

Canberra was then a town of some 122,000 people, ending geographically at Woden and Aranda. We lived in hostels - the Kurrajong and Lawley House I recall well. Social life centered on places like the Burns Club, the Italian Club, the Rugby Union Club and the Eastlake Football Club. We watched the moon landing in July 1969 in our offices - on black and white television. It was said later that if Goulburn had the big merino and various towns in Queensland their big bananas and pineapples, then Canberra deserved the big grey cardigan. But those who took that view risked overlooking the colour that really did exist in the mix of larger-than-life characters from the press, Parliament House and parts of the public service which was at its best at the Wellington Hotel on Friday nights.

The 20,000 or so public servants whom we joined in Canberra in 1969 constituted fewer than 10 per cent of all Commonwealth public servants. The workforce we joined was of course overwhelmingly male. It was only after 1966 that women could remain in the public service after they married, and the idea still had not 
caught on very well. Equal pay for women in the service was not mandated until 1969 with its implementation phased in through to 1973, and paid maternity leave was not available until 1973. But there were some powerful women in the workplace - they were in the typing pools and had our careers in their hands, or were pushing tea trolleys and purveying gossip vital to our futures. It was a workforce in which age and position went together because promotion was underpinned by seniority.

It was also a time in which accountability, by today's standards, was slight. Indeed, the word itself did not come into use for many years. There was no administrative law as we now know it - no ombudsman, no Administrative Decisions Judicial Review Act, no Administrative Appeals Tribunal, and no Freedom of Information Act. Parliamentary committee hearings were few there were no Senate estimates hearings before 1970. As far as I have been able to find out, Sir Arthur Tange, that most eminent predecessor of mine, only ever attended two parliamentary committee hearings - the first was to present a Defence submission to the Public Works Committee in 1978; the second an appearance before the Privileges Committee on a personnel matter after he retired. Departmental secretaries were then 'permanent heads' and remained so until 1994. They certainly did not see themselves as CEOs. The word 'responsive' first entered the APS argot in the 1980s, when Peter Wilenski gave it some respectable philosophical underpinnings, but it was only in 1999 that it became enshrined in the Public Service Act. It was a time of great central authority.

The Australian Public Service environment was dominated by a monster called the Public Service Board. A Stalinist institution populated by people who knew little but their own arcane business, it had a veto over virtually everything that happened in the Public Service - the creation of positions, promotions and appointments (through the appeals system), conditions of service and organisational structures. You could not scratch yourself without consulting 'the Board'. In addition, there was an interdepartmental committee called the Overseas Visits Committee which vetted all proposals for overseas travel by public officials and often rejected agencies' bids or reduced their delegations.

Probity, thoroughness and good record-keeping were among the great strengths of the APS of the time, but it was also a service characterised by caste divisions and turf warfare. The castes existed formally in the form of four 'divisions': a fourth division existed for clerical and registry staff, typists and so on, and a third division for other non SES but nevertheless higher status officers. Informally, casteism was sustained more subtly through unofficial distinctions in some departments between 'professional' officers and 'administrative' officers. These distinctions were maintained in internal promotions and job preferment, and manifested among other places in tensions between relevant unions. 
As for the turf wars between departments, they were tough and real. Differences in policy, or - more often - over who had the right to advise on policy in particular areas, were fiercely fought in meetings at all levels and in vitriolic correspondence that often went to ministerial levels and were only ever partially settled at the Commonwealth Club. The ones of which I was most aware were those between the resource and primary industry departments, and between the foreign affairs and trade departments, in their various and changing names, but there were many others. They generated not just paper-based hostility but in many cases lasting personal enmities, some of which can still be found in relationships between people whose names remain well known in this town. The term 'whole of government' which we hear so much about today was then, I think, unknown. It was all sadly wasteful of energy and effort.

By offering this sketch of the APS as it was then, I have indicated some of the ways it has changed over these 38 years. The changes have been driven by a range of factors, some from within the service and successive governments, some from the changing nature of society and our economy and the wider world of which we have increasingly become a part. Many of the changes were driven by the Coombs Royal Commission of 1975-77 which had an enormous impact on the APS over the next two decades. A raft of internal and structural changes followed, together with the administrative law provisions which now shape so much of the way we work. After a series of further reviews, the 1980s and especially the 1990s saw more reforms, many in the areas of people and financial management and also in further decentralisation. This culminated in the enactment in 1999 of the new Public Service Act which gave agency heads clear responsibility for managing their staff in ways that would maximise agency performance.

Through all of this, as a result of both legislative and social change and of course market demand, women have become a significant part of the service in both numbers and influence. In 1969, 21 per cent of Commonwealth public servants were women; today, the figure is 56 per cent. And I cannot forget the smoking. The effectiveness and speed with which it was turned off in the workplace was remarkable. By December 1988, when the wife of a government minister reportedly left an item of underwear in an ashtray on his desk after a late night visit to his office, most of us were surprised only by the fact that he still had an ashtray in his office. It was not just attitudes to smoking that had changed! Consider now some of these principal changes. 
With the benefit of hindsight

\section{Public service change: the numbers}

In talking about public service change in the broadest sense, it is hard to go further without talking about numbers. In 1969, there were nearly 219,000 Commonwealth public servants. That number continued to grow, reaching its zenith in 1975 with a figure of some 277,500. It then declined steadily, reaching 143,000 in 1996 and 113,500 in 2000. Today it stands at about 146,500, of whom some 52,000 - or about 36 per cent - are in Canberra. This contrasts with the fewer than ten per cent who were Canberra-based in 1969. In reflecting on these numbers it is necessary of course to take account of the enormous structural changes that lie behind them. The big numbers of the 1970s included government-owned businesses like the PMG and the shipyards and munitions factories which have long since been divested.

Even the more recent apparent growth reflects changes of a structural kind, such as the inclusion for the first time this year of around 5000 employees from Medicare. So in effect the raw numbers reflect how often and how significantly the definition of what is the business of government has changed over these years.

\section{The information revolution}

If the numbers have been affected by what the public service does, they have also been affected by technology, especially information technology. Computerisation, to use an old-fashioned term, ranks with the employment of women as the biggest change in the public service workplace in my working life. From manual typewriters to electric typewriters to word processors to whatever we call them today; from 'man-drolically' typed telegrams encoded with 'one-time-pads' to automatically encrypted e-mails, the change has truly been a revolution because it has affected not only the tools of our work but what we do, how we approach it and what is expected of us.

Interestingly, when computers were introduced into the public service they were seen as a means by which staff savings could be achieved, euphemistically called 'productivity gains'. It took a long time for us to realise that the true significance of IT went beyond the tools of our trade; that we were in fact caught up in an information revolution that was changing the volume, pace and nature of all that we did and the way we related to each other. Partly because we were slow to realise this, successive governments underestimated the scale of the investment required, and at various stages were panicked into new or more radical ways of providing and managing the essential ingredients of the revolution. If IT has been the biggest change factor in my time in the public service, it has also - partly for that reason - been the most difficult issue to manage. 
Nor is its management getting any easier. We now better understand both the nature and scale of the investment needed and have plenty of good advice about ensuring that our business drives our IT needs, not the reverse. But we are faced with managing the cultural and other consequences of the sheer volume of our transactions. As an illustration, each day my own organisation generates on average some 1.7 million e-mails and receives 680,000 e-mails from external sources - of which 470,000 (or almost 80 per cent) are spam. I see few greater challenges for the public service of the future than managing its IT. The issues will include those of costs, of project managing in an environment of rapid technological change, and of network security - as well of course as that already sorely taxing matter, records management.

\section{Ministers' offices and staff}

While the role and number of women in the service and the information revolution have been two of the great internal changes of the past 38 years, the third great change to the way the government is run and by whom has been the growth in ministerial staff and the role of ministerial offices. It has been fashionable among older public servants to lament this change. That is not my purpose here. Rather, it is to note the reasons for it and its significance. Nor are my comments in any sense partisan. The growth has in fact been bipartisan.

While the figures for 1969 are not available, I understand that in 1972 there were 150 people employed in ministers' offices. By 1983 the number stood at 207 , and today there are 415, including those in the offices of the parliamentary secretaries. From personal observation, I know there were four staff in the Canberra office of our first Foreign Minister, Billy McMahon, in 1970. All were public servants on some sort of secondment. Their role was to manage his paperwork and his diary, and not to give policy advice. Today, most ministers have six to eight advisers in addition to a number of other support staff. Some of the staff concerned are of course departmental liaison officers employed under the Public Service Act who do a great job in moving paper between ministers and their departments, but most are now employed under the MOPS Act.

The numbers have not been the only thing to change. More importantly, the work done by staffers has changed, and over the years has extended much beyond paper and diary management to include advising on the full range of a minister's responsibilities. In effect, by comparison with 1969, we now have a whole new layer or level of government. Why have these changes occurred? The move to the new Parliament House in 1988 is of course a part of the answer. Indeed, the new House did much more than just facilitate larger ministerial offices; it also created a completely new physical environment for the doing of 
government business. Consequently, ministers go to their departments much less often - indeed, only rarely. And the Wellington Hotel - or the Hotel Canberra back bar, or the rose garden - are no longer places of business with ministers: Parliament House is a complete village, and provides all the venues needed.

That said, there have been other more profound reasons for the growth in the numbers and roles of ministerial staff. They include the information revolution, and what I call democratisation. The information revolution has not only generated greater volumes of data which needs to be known to and processed by ministers, but it has also dramatically changed the velocity and timeliness of business. Government has become a '24 by seven' business, and information has become instant and global in its origins. Government departments and agencies, proceeding at their more stately paces and necessarily placing a high premium on thoroughness and clearly traceable lines of accountability, have been unable to meet all of their ministers' needs.

Departments have also struggled in their responses to the democratisation process. By this I mean three things. The first is the increased need of ministers to be able to respond to and participate in what we sometimes rather grandly call the 'public debate'. This means principally the media and parliament itself, but also other forums in which the business of government is scrutinised, the number, reach and expectations of which have grown with the information revolution. Second, ministers in this communications-rich environment are anxious to shape the presentation of their business to suit their electoral needs, and this is an area into which public servants cannot and should not cross.

And third, the information revolution - and globalisation more generally together with greatly increased demands for accountability, have required ministers to know about, be involved in and make decisions on a wider and deeper range of issues than ever. Ministerial staff are thus critical to the identification of issues for ministers and to managing the enormous volume of material which consequently comes to them.

All of this results in an unmistakably different policy advising and management environment and a different set of relationships between ministers and their departments than existed 30 years previously. There are a number of consequences of this situation that secretaries and other senior public servants need to be aware of. One is that there is another layer of government, and another source of advice to ministers, not always transparent to the department itself. Another is that dealing with ministers' offices is a critical job-skill for many public service positions: the days are long gone when a departmental secretary could refuse to take a call from a staffer in what was then called the 'private office'. 
Further, experience in a ministerial office is increasingly regarded as a significant career enhancer. These are fairly self-evident consequences of the growth of ministerial offices, but there are more profound aspects of the subject and the process of democratisation that it reflects. One of these is that ministers have acquired the resources and capacity to reach further into the management of their agencies, and for reasons of perceived accountability, want to do so. But as a former senior colleague once put it, this risks their becoming the effective CEO, and secretaries becoming in effect their Chief Operating Officers. If that becomes the case, then the respective accountabilities of ministers and secretaries may have to be changed in areas affected not only by convention but also by legislation. The obverse of this issue is the need for secretaries - and indeed public officials generally - to understand that many more of their decisions and actions today are likely to have a policy or even political impact than was the case in the past.

There are no simple responses or formulae for managing these issues. They are all part of what ministers and their secretaries deal with. But if we were looking for steps that could be taken to improve working relationships and the understanding of accountabilities, I would offer the suggestion that newly-appointed ministers and possibly aspiring back-benchers and newly-appointed secretaries or agency heads might be given the opportunity to attend workshops or seminars on the respective roles and responsibilities of ministers, secretaries and other departmental officers under our Westminster-with-Canberra system. This would include addressing their respective roles and responsibilities under the Public Service Act, the FMA Act, the FOI Act, and other relevant legislation. It would also embrace the less formal conventions that support the ministerial-public service relationship. Lest this be thought to be an unduly radical suggestion, I should hasten to say that something like it now runs in the UK.

The matter of a code of conduct for ministerial staff has of course been raised by others in the past. I believe the APS has benefited from its code, not just as a statement of values and an instrument of accountability, but also - as I can attest from experience - as a valuable tool of personnel management. It would not be easy to draft such a code for ministerial staff, involving as it probably would the very contentious question of who would enforce it and possibly also the need to define where ministers' offices end and departments or agencies begin. I suspect the debate on this issue has some distance to run.

I referred earlier to the increasing volume of material going to ministers in the form of briefs, submissions and so on. My own department is a case in point, and from what I hear, not unique. In 2000-01, we sent 2111 briefs or submissions to the minister; by 2005-06, the number had reached 5958. In 2000-01, we put forward 45 Cabinet submissions; in 2005-06, the number was 89. In a positive sense, this tells us that government is working as it should and that ministers 
With the benefit of hindsight

are making the real decisions, as they should. But it also risks overwhelming ministers, and that cannot make for good government. This too is a significant issue which requires a clear understanding between ministers and secretaries about what is wanted, and is certainly not an easy matter to resolve.

\section{Risk in the public service}

One further issue on which I would like to venture a view is the growth in compliance requirements, both 'hard' and 'soft'. By 'hard' compliance requirements I mean the clearly legislated requirements, like the FMA Act or audit requirements, or those which are established by government policy. By 'soft' requirements I mean the plethora of directives, guidelines, procedural criteria and so on that we are required to have to deal with in a host of situations that may arise in the course of our work. These compliance requirements are often driven by fear of criticism and of litigation and compensation claims. They are often put in place in response to an administrative error or a breakdown in decision making or advising of ministers. They often substitute for, and indeed limit the scope for, common sense, values-based judgements. And in minimising the scope for reasonable risk-taking behaviour, rules and guidelines, they limit public service creativity and effectiveness.

Tony Blair recently commented very pertinently on this subject. In a speech on 26 May 2005 he argued that 'we are in danger of having a wholly disproportionate attitude to the risks we should expect to run as a normal part of life. This is putting pressure on public policy-making...to act to eliminate risk in a way that is out of all proportion to the potential damage... We cannot respond to every accident by trying to guarantee ever more tiny margins of safety. We cannot eliminate risk. We have to live with it, manage it. Sometimes we have to accept: no-one is to blame.' This too is a debate worth having.

\section{Changes in the international environment}

Let me divert from the public service for a few moments to say something about changes over these 38 years in the international environment, which has of course been the subject of my professional interest. In 1969, the Cold War was the defining feature or 'organising principle' in world affairs. The decolonisation process was yet incomplete, the pursuit of independence was a strong theme, and the notion of sovereignty as a precious commodity was being nourished by the strength, rhetorically at least, of the recently decolonised nations in the United Nations. Apartheid ruled in South Africa, and anti-racism was a persistent theme in international affairs. Terrorism existed, but was arguably less global, 
and global security was defined almost exclusively by the interests of nationstates. Australia in 1969 was at war in Vietnam, and we regarded Taiwan as China. We were still adjusting to the UK's admission to the European Economic Community. We were a colonial power in the South Pacific, embarrassed unduly by that but optimistic about what an independent Papua New Guinea might make of itself. Like most other countries, we were highly protectionist. Our defence force then numbered nearly 89,000, with a civilian defence workforce of just over 39,000 , and in 1969-70 we spent 1.16 billion dollars or 3.2 per cent of our GDP on defence.

Our world today is defined by the word 'globalisation'. In 1969, the word itself was unknown, at least to me. We were aware of something called automatic data processing and of early generation computers, and we welcomed jumbo jets when they first flew commercially in 1970. But I do not think many of us picked these events then for what they were: the harbingers of globalisation. Australia did pick up on the trend by the 1980s though, and thereafter responded well to the new world with the result that we are now among the most globalised nations.

Looking back on these 38 years, four events stand out in my mind for their significance in shaping world affairs. Three - the rise of China, the end of the Cold War and the events of 9/11 - will not surprise you, but the fourth might: the fall of the Shah of Iran. This is not the place to try to add to all that has been said and written about the meaning and consequences of each of these events, but I would just proffer the view - consistent with the main subject of this address - that $9 / 11$ was probably one of the more significant contributing factors to the rediscovery of the role and importance of government in Western societies after the 'smaller government' fetish of the 1990s. If I may offer a view on the most significant Australian government decision of these 38 years in the realm of foreign and international security policy, it could only be the decision to intervene in East Timor in 1999. As to defence, since 1999 we have deployed some 90,000 personnel overseas on more than 30 operations. Our defence capabilities have truly come to make an important contribution to Australia's international standing. This we do with 51,000 ADF members, 18,000 civilian employees and 1.9 percent of GDP.

\section{Conclusion}

In addition to my first experience of war, my first overseas posting (in India for three years) gave me a keener understanding of government and how it was done. While I had long been interested in politics, to see another government at work - even one that looked like ours with a federal system, two houses of 
parliament and a robust public service - and to try to understand it and work with it, was a valuable learning experience about the nature of government. In the approximately thirty years since then, I have sustained that interest. In later postings in Israel, the Philippines, the United States, China and Indonesia, and in visiting and working in scores of other countries, I have always taken a close interest in how their governments work, and why some work better than others. In all of this one thing has been manifestly clear to me: whatever the constitution, the structure of government, the party system or the quality of political leadership, in the end little can be achieved without robust public institutions and an effective public service.

And a corollary of this is that, even in those countries which have had weak public institutions, the key to getting things done - for political leaders and foreign diplomats alike - is to find the best of the public servants available and try to work through them. They will invariably be overworked and much harried individuals, but I have seen whole governments virtually dependent upon a bare handful of them. From all of this I have become convinced that our own public service is one of the best. Others have reached the same conclusion, but my view is based on much experience watching and working with governments in many countries, and often trying to help struggling or even failing governments function. Frustrating, ponderous, and sometimes overweight: whatever their undoubted misgivings, our public servants are always there, always steady, generally very hard working and honest to a high degree. In short, the Australian Public Service is a national asset, and significantly under-recognised for the contributions it makes.

And yet, challenges nevertheless remain for our public service. I have already referred to IT management issues. Beyond that, I believe most of the challenges are in the personnel area. From talking to other secretaries, I know that many of us now are hard-pressed to recruit adequately for all the jobs we offer, and I know that a number of us have vacant SES positions for which we cannot identify suitably qualified applicants. Much is made in the defence world of the challenge of recruiting to the ADF; in truth, the public service is facing many similar challenges. In broad terms, we need to think more about the sort of people we want to replace us, and how we are going to recruit and train them, and do that much more deliberately.

More specifically, in the area of skills I believe that historically we have given corporate support and service delivery skills too little attention in the Australian Public Service. Traditionally, in part reflecting the old caste divisions I referred to earlier, we have attached greater weight to policy work than to service delivery and corporate work. This has been reflected among other ways in the allocation of SES positions. But it is contrary to the current trend in public sector management, which places increasing weight on accountability in spending 
money, managing assets and delivering services, and on project and contract management. I do believe we need to redress that imbalance. I referred earlier to toiling for 38 years in this vineyard. I did so, as I said, as a tradesman rather than a philosopher or a visionary. Beyond my normal competitive instincts and a desire to do the best I could, I also did it without any particular ambitions. I did not apply for my first two promotions, nor for my last. I simply kept turning up every day, and they kept doing it to me. I am glad they did, whoever they were. It has been a privilege to be able to serve 12 Foreign Ministers, seven Trade Ministers and three Defence Ministers.

It was also a privilege to have represented Australia abroad - in each of the world's four most populous countries as well as in places like Micronesia, the Marshall Islands, Palau and Mongolia. It was an honour to be appointed as the secretary of the government's largest organisation, the Department of Defence, and a privilege to serve alongside this generation's finest military leaders - in particular my 'co-diarchists' General Peter Cosgrove and Air Chief Marshal Angus Houston. The best times have had this in common: they have been those occasions in which public servants from many different agencies have come together to work as one team to deliver a clear result. Ironically, I saw this at its best in the aftermath of the Bali bombing, where incidentally I also saw some wonderful volunteer work by Australians. In a less dramatic but nevertheless gratifying way, I saw it as ambassador in Beijing from 1996 to 2000, where the embassy came together as one Australian team with the Australian business community to deliver some terrific results for Australia. And I saw it again in the strongly committed multi-departmental team I had in Jakarta in 2001 and 2002. 